www.jmscr.igmpublication.org Impact Factor 5.244

Index Copernicus Value: 83.27 ISSN (e)-2347-176x ISSN (p) 2455-0450 crossref DOI: https://dx.doi.org/10.18535/jmscr/v4i12.128

\title{
Neurological Manifestations in the Patients with HIV/AIDS
}

\author{
Authors \\ Dr Murugesh Pastapur ${ }^{1}$, Dr Maitrey Patel, Dr Rajiv S Konin ${ }^{3}$ \\ ${ }^{1}$ Associate Professor, Department of General Medicine, MRMC, Kalaburgi \\ ${ }^{2,3}$ PG Department of General Medicine MRMC, Kalaburgi
}

Department of General Medicine, Mahadevappa Rampure Medical College, Kalaburgi, Karnataka, India

Corresponding Author

Dr Maitrey Patel

11 Avi Bunglows, Opp Star Bazaar, Satellite Road, Ahmadabad 380015

Email: ptlmaitrey@gmail.com, M-7760378269

\begin{abstract}
Background: HIV/ AIDS has posed many unprecedented challenges. It causes a wide spectrum of disease manifestations. Neurological diseases is the first manifestation of symptomatic HIV infection in roughly 10 $20 \%$ of patients, while about $60 \%$ of patients with advanced HIV disease will have clinically evident neurological dysfunction during the course of their illness.

Objectives: To study the neurological manifestations in patients with HIVIAIDS admitted to MRMC, Gulbarga and to note differences with various other studies carried out in India and in western countries and to evaluate simpler and cost effective diagnostic techniques.

Methods: A total of 50 patients admitted in medicine wards in Basaveshwar Teaching \& General Hospital attached to M.R. Medical College, Gulbarga during a study period between November 2009 and September 2011, who were found to have HIV infection and history suggestive of nervous system manifestations were enrolled in the study.

Results: Of the total 50 patients, 33 were males and 17 were females with M:F ratio of 1.95:1. 88\% of patients were between age group of 18-45 years. Meningitis was the most common neurological presentation (58\%), comprising 16 patients with tubercular meningitis (32\%), 7 patients with cryptococcal meningitis (14\%), 5 patients with aseptic meningitis (10\%), and 1 patient with bacterial meningitis (2\%).

Fever (66\%), headache (64\%), altered sensorium (38\%) and convulsions (34\%) were the commonest neurological symptoms. Tuberculosis was the commonest disease affecting CNS (38\%), with 16 patients having meningitis (32\%) and 3 patients having tuberculoma (6\%). The most common space occupying lesions was toxoplasmosis (10\%).

Conclusion: There is high incidence of neurological manifestations affecting mainly economically reproductive age group (18-45 years) with tuberculosis and cryptococci being the most commonest pathogenic agents in course of HIV infections in this study.
\end{abstract}

Keywords: Human immunodeficiency virus; Tubercular meningitis; Cryptococcus meningitis; Toxoplasmosis.

\section{Introduction}

At the end of 2013, an estimated 35.0 million individuals were living with HIV infection, according to the Joint United Nations Programme on HIV/AIDS (UNAIDS). HIV/ AIDS has generated so much concern because of rapid 
dissemination, long incubation period, specific health problem, fatal outcome and great socioeconomic impact.HIV/ AIDS cause a wide spectrum of diseases and manifestations. Up to $70 \%$ of HIV patients develop neurological complications. It is not surprising that neurological complications of HIV infections are common and not confined to opportunistic infections. All levels of the neuraxis can be involved, including the brain, meninges, spinal cord, nerve and muscle. Neurological disease is the first manifestation of symptomatic HIV infection in roughly 10-20\% of persons, while about $60 \%$ of patients with advanced HIV disease will have clinically evident neurological dysfunction during the course of their illness ${ }^{1-3}$.

Hence, recognition and early diagnosis of these disorders is crucial because institution of therapy may dramatically change patients quality of life and survival time.

\section{Material and Method}

Randomly 50 patients with HIV positive and history suggestive of Nervous system manifestation from November 2009 to September 2011 admitted in Basaveshwar hospital and
General Hospital attached to Mahadevappa Rampure Medical College, Gulbarga were selected as study sample. Confirmation of HIV status was done as per the guidelines given by WHO/ NACO. Total 50 number of cases were randomly selected.

\section{Inclusion criteria}

All patients with neurological manifestations and diagnosed to be HIV seropositive in age 15-65.

\section{Exclusion criteria}

HIV patients with diabetes mellitus, Collagen vascular disease ,HTN ,Vasculitis , Paraneoplastic syndrome

\section{Method of Data Collection}

Data was collected in a pretested proforma by meeting the objective of the study. A detailed history, physical findings with thorough neurological examination and necessary investigations were recorded. Treatment and outcome were not included in this study.

Investigations were done-TRIDOT (Rapid Visual Test), ELISA, CD4 count, CSF analysis, CT scan/ MRI (wherever required), Serology to detect antibody to toxoplasma and CMV, cryptococcal antigen test,Chest X-ray.

\section{Results}

Table-1: Age and sex distribution

\begin{tabular}{|c|c|c|c|c|c|c|}
\hline \multirow{2}{*}{$\begin{array}{l}\text { Age of patient } \\
\text { (years) }\end{array}$} & \multirow{2}{*}{$\begin{array}{c}\text { No. of } \\
\text { patients }\end{array}$} & \multirow{2}{*}{ Percentage } & Males & & Female & \\
\hline & & & Number & Percent & Number & Percent \\
\hline $18-25$ & 8 & 16.00 & 5 & 10.00 & 3 & 6.00 \\
\hline $26-35$ & 17 & 34.00 & 11 & 22.00 & 6 & 12.00 \\
\hline $36-45$ & 19 & 38.00 & 13 & 26.00 & 6 & 12.00 \\
\hline $46-65$ & 6 & 12.00 & 4 & 8.00 & 2 & 4.00 \\
\hline Total & 50 & 100.00 & 33 & 66.00 & 17 & 34.00 \\
\hline
\end{tabular}

From the above table, it can be observed that male constitute 33 cases $(66 \%)$, while females constituted $17(34 \%)$ with male-female ratio of 1.95:1. The mean age among males was 35.3 years and in female it was 35.5 years. In this observation, $88 \%$ of patients were between 18-45 years of age. There were $84 \%$ cases, who were married. Among these 84\%, males constituted $52 \%$ and females $32 \%$. Only 8 patients were unmarried.

Neurological manifestations heralded the onset of HIV in $60 \%$ of the cases. $40 \%$ of the cases were diagnosed to have HIV prior to admission. 98\% patients had contracted the disease sexually. Most 


\section{JMSCR Vol||04||Issue||12||Page 15093-15098||December}

of them had the history of multiple exposure i.e., heterosexual behaviour. One (01) person contracted HIV through injection drug use. No patient had any history of transmission through blood transfusion.

Table-2: Neurological signs and symptoms

\begin{tabular}{|l|c|c|c|c|c|}
\hline Route & $\begin{array}{c}\text { No. of } \\
\text { patient } \\
\text { S }\end{array}$ & $\begin{array}{c}\text { Percentage } \\
\%\end{array}$ & CNS signs & $\begin{array}{c}\text { No. of } \\
\text { patients }\end{array}$ & $\begin{array}{c}\text { Percenta } \\
\text { ge\% }\end{array}$ \\
\hline Headache & 32 & 64.00 & HMF & 19 & 38.00 \\
\hline Fever & 33 & 66.00 & Cranial nerve & 3 & 6.00 \\
\hline Altered sensorium & 19 & 38.00 & $\begin{array}{c}\text { Abnormal } \\
\text { fundus }\end{array}$ & 14 & 28.00 \\
\hline Convulsions & 17 & 34.00 & Motor system & 9 & 18.00 \\
\hline Weakness of limbs & 9 & 18.00 & Sensory system & 3 & 6.00 \\
\hline Sensory deficits & 4 & 8.00 & Cerebellar signs & 1 & 2.00 \\
\hline B/B disturbance & 4 & 8.00 & Gait & 3 & 6.00 \\
\hline Giddiness & 2 & 4.00 & Meningeal signs & 23 & 46.00 \\
\hline
\end{tabular}

Out of 50 patients, most common presenting symptom is fever in 33 patients $(66 \%)$, followed by headache in 32 patients $(64 \%)$, altered sensorium $38 \%$ and convulsions in $34 \%$ of cases.
Out of 50 patients, 32 patients had $\mathrm{CD}_{4}$ count in between 51-200 (64\%), and 16 patients had $\mathrm{CD}_{4}$ count between 201-500 (32\%) and 2 patients had $\mathrm{CD}_{4}$ count less than $50(4 \%)$.

Table 3: - CSF Analysis in meningitis

\begin{tabular}{|l|c|c|c|c|}
\hline $\begin{array}{l}\text { CSF } \\
\text { Analysis }(\text { mean} / \mu \mathrm{l})\end{array}$ & Cryptococcus & Tuberculos & Aseptic & bacterial \\
\hline Cell & 79 & 294 & 85 & 900 \\
\hline Protien & 84 & 180 & 112 & 350 \\
\hline Sugar & 46 & 38.5 & 46 & 29 \\
\hline
\end{tabular}

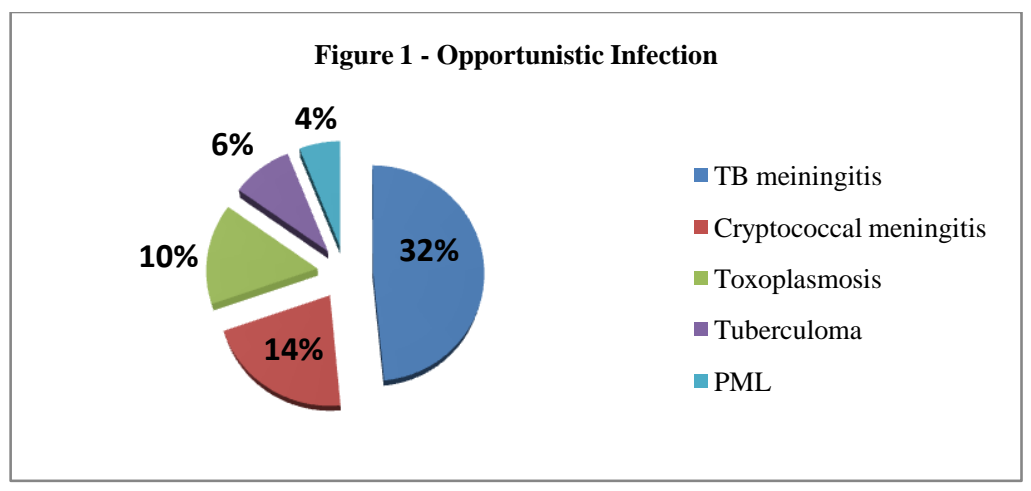

Figure 1 shows, Out of 50 patients, most common opportunistic infection is tubercular meningitis (32\%), followed by cryptococcal meningitis (14\%), toxoplasmosis (10\%), tuberculoma (6\%) and progressive multifocal leukoencephalopathy $(4 \%)$. 


\section{JMSCR Vol||04||Issue||12||Page 15093-15098||December}

Table-4: - Mean $\mathrm{CD}_{4+} \mathrm{T}$ cell count of patients with different neurological diseases

\begin{tabular}{|l|c|c|c|c|}
\hline Disease & No. of patients & Percent & CD $_{\mathbf{4 +}}$ T range (cells/ $\left.\boldsymbol{\mu L}\right)$ & $\begin{array}{c}\text { Mean }_{\mathbf{C}} \mathbf{C D}_{\mathbf{4}} \mathbf{T} \\
\text { count }(\text { cells/ } \boldsymbol{\mu L})\end{array}$ \\
\hline TBM & 16 & 32.00 & $86-300$ & 193 \\
\hline Toxoplosmosis & 5 & 10.00 & $58-150$ & 104 \\
\hline Tuberculoma & 3 & 6.00 & $154-271$ & 212 \\
\hline Cryptococcal meningitis & 7 & 14.00 & $15-235$ & 125 \\
\hline PML & 2 & 4.00 & $40-68$ & 54 \\
\hline Aseptic meningitis & 5 & 10.00 & $86-270$ & 178 \\
\hline Bacterial meningitis & 1 & 2.00 & 160 & 91 \\
\hline Transverse myelitis & 2 & 4.00 & $56-127$ & 210 \\
\hline AIDP & 4 & 8.00 & $120-300$ & 82 \\
\hline HIV encephalopathy & 2 & 4.00 & $60-104$ & 375 \\
\hline Idiopathic epilepsy & 2 & 4.00 & $350-400$ & 350 \\
\hline Myopathy & 1 & 2.00 & 350 & \\
\hline
\end{tabular}

\section{Discussion}

The age ranged from 18 to 65 years. Mean age was 35 years (M-35: F-36) with $\mathrm{M}$ : $\mathrm{F}$ ratio is 1.95:1. Satya et $\mathrm{al}^{4}$ in his study observed male to female ratio of 3.7:1. Fragoso et $\mathrm{al}^{5}$ in his study observed male to female ratio of 1.94:1. In this present study, the most common route of transmission was heterosexual (98\%). This finding correlated with Sourab et al ${ }^{6}(89.26 \%)$ and Deshpande et $\mathrm{al}^{7}(92.5 \%)$ in which most common route of transmission was heterosexual. This is in contrast to the western studies where homosexual transmission is more common.

Table-5: Comparison of Neurological symptoms and signs with other studies

\begin{tabular}{|c|c|c|c|}
\hline Symptoms and signs & $\begin{array}{l}\text { Satya } \\
(n=57)\end{array} \quad$ et al $^{4}$ & $\begin{array}{l}\text { Bolokadze et } \\
\text { al }^{7}(n=76)\end{array}$ & $\begin{array}{l}\text { Present study } \\
(n=50)\end{array}$ \\
\hline Headache & $40(70 \%)$ & $69(91 \%)$ & $32(64 \%)$ \\
\hline Fever & $42(73.6 \%)$ & $57(75 \%)$ & $33(66 \%)$ \\
\hline Altered sensorium & $18(31.5 \%)$ & -- & $19(38 \%)$ \\
\hline Focal neurological deficits & $13(22.8 \%)$ & $46(61 \%)$ & $9(18 \%)$ \\
\hline Seizures & $26(45 \%)$ & $12(15 \%)$ & $17(34 \%)$ \\
\hline Meningeal signs & $40(70 \%)$ & -- & $23(46 \%)$ \\
\hline Papilloedema & $20(35 \%)$ & -- & $14(28 \%)$ \\
\hline
\end{tabular}

Most of the patients presented with headache $(64 \%)$ and fever $(66 \%)$ as the most common complaint. This is also seen in the studies conducted by the Satya et $\mathrm{al}^{4}(70 \%$ and $73 \%$ respectively) and Bolokadze et $\mathrm{al}^{9}(91 \%$ and $75 \%$ respectively). But the meningeal signs are commonly seen in Satya et $\mathrm{al}^{4}$ study when compared to the present study as per table 5 .

Table 6 :- Comparison of opportunistic infections with other studies

\begin{tabular}{|l|c|c|c|}
\hline Opportunistic infection & $\begin{array}{c}\text { Satya et } \\
\mathbf{a l}^{\mathbf{4}}(\mathbf{n = 5 7})\end{array}$ & $\begin{array}{c}\text { Deshpande et } \\
\mathbf{a l}^{\mathbf{7}} \mathbf{( n = 3 0 0 )}\end{array}$ & $\begin{array}{c}\text { Present study } \\
(\mathbf{n = 5 0})\end{array}$ \\
\hline Tubercular meningitis & $25(43.8 \%)$ & $24(8 \%)$ & $16(32 \%)$ \\
\hline Toxoplasmosis & $5(8.7 \%)$ & $61(20.3 \%)$ & $5(10 \%)$ \\
\hline Cryptococcal meningitis & $16(28.1 \%)$ & $51(17.0 \%)$ & $7(14 \%)$ \\
\hline Tuberculoma & $1(1.75 \%)$ & $48(16 \%)$ & $3(6 \%)$ \\
\hline Progressive multifocal leucoencephalopathy & $3(5.26 \%)$ & $20(6.6 \%)$ & $2(4 \%)$ \\
\hline
\end{tabular}




\section{JMSCR Vol||04||Issue||12||Page 15093-15098||December}

Table 6 shows, the most common opportunistic infection in the present study is tubercular meningitis (32\%) followed cryptococcal meningitis $(14 \%)$. This is also seen in the study conducted by Satya et $\mathrm{al}^{4}$, where the most common opportunistic infection is tubercular meningitis $(43.8 \%)$ followed by cryptococcal meningitis (28.1\%).In Deshpande et $\mathrm{al}^{7}$ study, toxoplosmosis is more common opportunistic infection, but the sample is very huge when compared to the present study.In this study 2 cases (4\%) of PML was diagnosed, Satya et $\mathrm{al}^{4}$ reported $5.26 \%$ of their patients having PML. Levy et $\mathrm{al}^{8}$ reported $2 \%$ of their patients having PML.

Table-7: Comparison of mean $\mathrm{CD}_{4}$ count with other studies

\begin{tabular}{|c|c|c|c|}
\hline Opportunistic infection & $\begin{array}{l}\text { Satya et } \mathbf{a l}^{4} \\
\quad(n=57)\end{array}$ & $\begin{array}{l}\text { Deshpande et } \\
\text { al }^{7}(n=300)\end{array}$ & $\begin{array}{l}\text { Present study } \\
\quad(n=50)\end{array}$ \\
\hline Tubercular meningitis & $190(25)$ & $160(24)$ & $193(16)$ \\
\hline Toxoplosmosis & $115(5)$ & $150(61)$ & $104(5)$ \\
\hline Cryptococcal meningitis & $135(16)$ & $114(51)$ & $125(7)$ \\
\hline $\begin{array}{l}\text { Progressive multifocal } \\
\text { leukoencephalopathy }\end{array}$ & $104(3)$ & $108(20)$ & $54(2)$ \\
\hline AIDP & -- & $395(4)$ & $210(4)$ \\
\hline Tuberculoma & -- & $212(48)$ & $212(3)$ \\
\hline
\end{tabular}

Table 7 shows In almost all of the diseases, the mean $\mathrm{CD}_{4}$ count are well correlated with the studies conducted by Satya et $\mathrm{al}^{4}$ and Deshpande et $\mathrm{al}^{7}$ except AIDP. In Deshpande et al7 study, the mean $\mathrm{CD}_{4}$ count in AIDP is 395 cells $/ \mu \mathrm{L}$, when compared to the present study (210 cells $/ \mu \mathrm{L})$. According to DM Simpson et $\mathrm{al}^{10}$, the condition generally occurs early in the course of HIV disease and may be the initial clinical disorder when seroconversion occurs. When AIDP occurs late in the course of HIV disease, in association with a low $\mathrm{CD}_{4}$ count, cytomegalovirus may be the primary etiologic agent. So in this scenario CMV may be the etiological agent, which is causing AIDP in the present study, which is unable to diagnose in our set up.

\section{Conclusion}

Neurological manifestations in HIV/ AIDS are frequent complications which may affect every level of the nervous system. In the present study, $60 \%$ of the patients presented with neurological pathology and were diagnosed to have HIV/ AIDS thereafter. Most common affected age group ranged from 18-45 years with male:female ratio of 1.95:1. This indicate the high prevalence of HIV in economically reproductive age group. Meningitis was the most common neurological presentation in HIV infection in this study i.e., $58 \%$.Tuberculosis is the commonest disease affecting CNS (38\%).Headache and fever were the commonest symptoms in HIV patients with neurological pathology. Most common space occupying lesion in the CNS is toxoplosmosis $(10 \%)$.Most number of patients $(64 \%)$ are seen in the $\mathrm{CD}_{4}$ range in between $51-200$ cells/ $\mu \mathrm{L}$.CSF analysis was done in most of the cases and was useful in diagnosing cryptococcal meningitis and providing clue to tubercular pathology.

\section{Limitation}

This is a small study carried out over stipulated period of time in a small population and does not indicate the true incidence of prevalence of the disease in the community.

\section{References}

1. Levy RM, Bredesen DE, Rosenblum ML. Neurological manifestations of the acquired immunodeficiency syndrome (AIDS): Experience at UCSF and review of the literature. J Neurosurg 1985 Apr; 62(4): 475-95. 
2. Koppel BS, Wormser GP, Tuchmon AJ, Mooyan S, Hewlett D Jr, Daros M. Central nervous system involvement in patients with acquired immunodeficiency syndrome (AIDS). Acta Neurol Scand 1985 May; 71(5): 337-53.

3. Snider WD, Simpson DM, Nielson $\mathrm{S}$, Gold JW, Metroka CE, Dosner JB. Neurological complications of acquired immunodeficiency syndrome: Analysis of 50 patients. Ann Neurol. 1983 Oct; 14(4): 403-18.

4. Satya A, Gulati A, Singh V, Varma D, Rai $\mathrm{M}$, Sunder $\mathrm{S}$; et al. Neurological Manifestation HIV infected patients around Varanasi, India: AJNS/2006/Vol 25 No 1

5. Fragoso YD, Mendes V, Adamo APM, Bosco LP, Tavares CAF; et al. Neurologic manifestations of AIDS: a review of fifty cases in Santos Rev Paul Med 1998; 116(3):1715-20.

6. Sourab Varma,Annil Mahajan, JB Singh, Manoj Sharma; et al. Clinical profile of HIV/AIDS patients in Jammu: JKPractitioner 2006; 14(2):79-83.

7. A.K.Deshpande, Mrinal M Patnaik; et al. Nonopportunistic Neurological Manifestations of theHuman Immunodeficiency Virus:An Indian Study, Journal of The International AIDS Society 2005,7:2

8. Levy RM, Bredesen DE, Rosenblum ML. Neurological manifestations of the acquired immunodeficiency syndrome (AIDS): Experience at UCSF and review of the literature. J Neurosurg 1985 Apr; 62(4): 475-95.

9. Bolokdze N, Gabunia P, Ezugbaia M, Gasterelia L, Khechiashvili G; et al. Neurological complications in patients with HIV/AIDS. Georgian Med News 2008 Dec; (165):34-8.

10. Simpson, David M.; Tagliati, Michele; et al. Neurologic Manifestations of HIV
Infection: Ann Intern Med, Volume 121(10).November 15, 1994.769-785. 